\title{
Influence of Stylus System Configuration on the Variability of Measurement Result on CMM
}

\section{Petr Mikeš}

Department of Machining, Process Planning and Metrology, Faculty of Mechanical Engineering, Czech Technical University in Prague, Technická 4, 16607 Praha 6, E-mail: p.mikes@fs.cvut.cz

The article deals with the measurement on CMMs with tactile stylus system. Accuracy of CMM is mostly indicated by the parameter MPEE (Maximum Permissible Error for length measurement). This parameter refers to an errors during the measurement of distance between two points in space. Verification of MPEEparameter is described in an ISO standard 10 360-2 Acceptance and re-verication tests for coordinate measuring machines. These acceptance and re-verification tests are often conducted with a short and stiff reference stylus which is not and also mostly cannot be used in real measurements. On the contraryin applications such as a measurement of engine blocks and transmission housings very complex styli configurations are used. The influence of stylus system configuration on the variability of measurement when using long extensions, different materials (aluminium, carbon fiber composites) and high scanning speed in not described. The aim of this article is to design a methodology for testing the styli systems used in complex metrology applications in quality control of hi-precision mechanical components, to analyze the contribution of stylus system configuration to the measurement system variability in the form of a standard measurement uncertainty described by standard deviation.

Keywords: Coordinate Measuring Machines, stylus system, variability of measurement result

\section{References}

[1] BOSH, J. (1995). Coordinate measuring machines and systems. New York: MARCELL DEKKER, 444s

[2] Inspection Engineering. Zeiss contact sensors [online]. 1.6.2013. 2013 [cit. 2013-06-15]. Dostupné z:http://www.inspectionengineering.com/Zeiss_Contact_Sensors.htm

[3] BERÁNEK, L. (2013). Využití souřadnicové měřicí techniky v moderních procesech kontroly kvality, In: 6. Odborný seminář Kvalita a rizika ve výrobě. Jaroměř: Centrum pro povrchové úpravy, s. 50-53. ISBN 978-80-87583$05-0$.

[4] RATAJCZYK, E. (2005). Wspolrzednosciowa technika pomiarowa. Warszawa: Oficyna Wydawnica Politechniki Warszawskiej, $356 \mathrm{~s}$.

[5] PFEIFER, T., IMKAMP, D., SCHMITT, R. (2006). Coordinate Metrology and CAx-Application in Industrial Production: Basic, Interfaces and Integration, Munich: Carl Hanser Verlag, $205 \mathrm{s.}$

[6] VASILKO, K., MURČINKOVÁ, Z. (2013). Analysis of geometric accuracy of turned workpieces. Manufacturing Technology, 13(2), 247-252.

[7] IŽOL, P., FABIAN, M., KOPAS, M., FEDORKO, G. (2013). Evaluation of machining strategies for productionof free form surfaces using 3-axle milling. Manufacturing Technology, 13(4), 458-465. 